\title{
The Structural and Electrochemical Properties of Thermally Aged $\mathrm{Li}\left[\mathrm{Co}_{0.1} \mathrm{Ni}_{0.15} \mathrm{Li}_{0.2} \mathrm{Mn}_{0.55}\right] \mathrm{O}_{2}$ Cathodes
}

\author{
Yong Joon Park, ${ }^{\dagger, \star}$ Ju Wook Lee, ${ }^{+}$Young-Gi Lee, Kwang Man Kim, Man Gu Kang, and Youngil Lee ${ }^{\$, *}$ \\ Ionics Device Team, Electronics and Telecommutications Research Institute, Daejeon 305-350, Korea \\ ${ }^{\dagger}$ Division of Advanced Industrial Engineering, Kyonggi University, Gyeonggi 443-760, Korea \\ "E-mail: yjpark2006@hyonggi.ac.kr \\ \$Semiconductor Process Team, Electronics and Teleconmunications Research Institute, Daejeon 305-350, Korea \\ ${ }^{\S}$ Department of Chemistry, University of Ulsan, Ulsan 680-749, Korea. "E-mail: mmyil@ulsanac.kr \\ Received April 17, 2007
}

\begin{abstract}
$\Lambda$ s a cathode material of lithium rechargeable batteries, charged $\mathrm{Li}\left[\mathrm{C} \mathrm{C}_{0.1} \mathrm{Ni}_{0.15} \mathrm{Li}_{0.2} \mathrm{Mn}_{0.55}\right] \mathrm{O}_{2}$ electrodes, which were aged thermally at $25^{\circ} \mathrm{C}$ and $90^{\circ} \mathrm{C}$ respectively, were characterized by means of charge/discharger, impedance spectroscopy, and X-ray diffraction. The discharge capacity diminution of the electrodes aged at 25 ${ }^{\circ} \mathrm{C}$ and $90{ }^{\circ} \mathrm{C}$ for 1 week was $4 \%$ and $23 \%$, respectively. The cell aged at $25^{\circ} \mathrm{C}$ was recovered on cycling. IIowever, the capacity loss after ageing at $90^{\circ} \mathrm{C}$ was not recovered in a subsequent cycling test, which demonstrates that the reaction occurring during ageing at $90^{\circ} \mathrm{C}$ is irreversible. $\Lambda$ significant impedance increase of aged electrode at $90^{\circ} \mathrm{C}$ is associated with irreversible capacity loss. The structural changes including phase transformation were not detected by XRD analysis, because it could be due to out of detection limit. $\Lambda \mathrm{fter}$ ageing, impedance was slightly decreased during subsequent cycling test. It could be explained the cyclic performance of aged sample is stable. The thermal stability was not deteriorated by ageing even at the high temperature of $90^{\circ} \mathrm{C}$.
\end{abstract}

Key Words : Cathode, Lithium rechargeable battery, Thermally aged, Electrochemical, Impedance

\section{Introduction}

Mn-based layered oxides are of interest as the cathode material for lithium ion batteries due to their low cost, safety, and environmental compatibility. ${ }^{1-16}$ In particular, their higher specific capacity compared to commercial cathode materials such as $\mathrm{LiCoO}_{2}$ is an impressive benefit. Several methods have been used to prepare Mn-based layered oxides such as hydroxide co-precipitate ${ }^{4.5}$ and simple combustion methods, ${ }^{1,11-16}$ and stable cyclic performance and structural stability were achieved by earlier research. However, further investigation of other essential properties, such as thermal stability and ageing properties in the charged state, is necessary for commercialization.

In this paper, studies of the ageing properties of a $\mathrm{Mn}$ based oxide at room temperature and $90^{\circ} \mathrm{C}$ are presented. During the ageing period in the charged state, chemical reactions between the electrolyte and the surfaces of both electrodes reduce the amount of electricity, which is likely to have an adverse impact on the electrochemical characteristics. Moreover, if the ageing temperature is increased, the chemical reactions in the cell can damage the structural stability of the cathode or anode materials affecting capacity and cycle life. In this paper, the ageing properties of $\mathrm{Li}\left[\mathrm{Co}_{0.1} \mathrm{Ni}_{0.15} \mathrm{Li}_{0.2} \mathrm{Mn}_{0.55}\right] \mathrm{O}_{2}$ cathode material prepared by a simple combustion method was characterized. In our previous work, ${ }^{1} \mathrm{Li}\left[\mathrm{Co}_{0.1} \mathrm{Ni}_{0.15} \mathrm{Li}_{0.2} \mathrm{Mn}_{0.53}\right] \mathrm{O}_{2}$ was found to have a high discharge capacity and stable cycle life. Therefore, it is a promising Mn-based oxide material with a layered structure. The substitution of some portion of the transition metal ions with lithium ions in the transition metal layer leads to high discharge capacity. The ageing properties of $\mathrm{LiCoO}_{2}$ and $\mathrm{LiMn}_{2} \mathrm{O}_{4}$ at $75^{\circ} \mathrm{C}$ were investigated by XRD and TEM analysis, ${ }^{17}$ and those of $\mathrm{LiNi}_{0.5} \mathrm{Mn}_{1.5} \mathrm{O}_{4}{ }^{18}$ and $\mathrm{LiNi}_{0.8} \mathrm{CO}_{0.15} \mathrm{Al}_{0.05} \mathrm{O}_{2}{ }^{19}$ were characterized by an impedance analyzer. However, to the best of our knowledge, $\mathrm{Li}\left[\mathrm{CO}_{0.1}\right.$ - $^{-}$ $\mathrm{Ni}_{0.15} \mathrm{Li}_{0.2} \mathrm{Mn}_{0.55} \mathrm{~J}_{2}$ and its derivative systems prepared by a simple combustion method have not been investigated. The charge retention of $\mathrm{Li}\left[\mathrm{Co}_{0.1} \mathrm{Ni}_{0.15} \mathrm{Li}_{0.2} \mathrm{Mn}_{0.55}\right] \mathrm{O}_{2}$ was investigated after ageing at room temperature and $90^{\circ} \mathrm{C}$. DSC, $\mathrm{XRD}$, and impedance analysis were also performed to understand the ageing mechanisms.

\section{Experimental}

$\mathrm{Li}\left[\mathrm{Co}_{0.1} \mathrm{Ni}_{0.15} \mathrm{Li}_{0.2} \mathrm{Mn}_{0,53}\right] \mathrm{O}_{2}$ (expected composition) was prepared by a simple combustion method from manganese acetate tetralhydrate $\left[\mathrm{Mn}\left(\mathrm{CH}_{3} \mathrm{CO}_{2}\right)_{2} \cdot 4 \mathrm{H}_{2} \mathrm{O}\right]$, nickel(II) nitrate hexahydrate $\left[\mathrm{Ni}_{(}\left(\mathrm{NO}_{3}\right)_{2} \cdot 6 \mathrm{H}_{2} \mathrm{O}\right]$, cobalt(III) nitrate hexalyydrate $\left[\mathrm{Co}\left(\mathrm{NO}_{3}\right)_{2} \cdot 6 \mathrm{H}_{2} \mathrm{O}\right]$, lithium nitrate $\left[\mathrm{LiNO} \mathrm{H}_{3}\right]$, and lithium acetate dihydrate $\left[\mathrm{CH}_{3} \mathrm{CO}_{2} \mathrm{Li} \cdot 2 \mathrm{H}_{2} \mathrm{O}\right]$. The starting materials were dissolved in distilled water and the solution was heated to $100^{\circ} \mathrm{C}$ until it formed a viscous gel. The gel was fired at $400^{\circ} \mathrm{C}$ for $1 \mathrm{hr}$ and a vigorous decomposition process occurred resulting in an ash-like powder. The decomposed powder was ground and heated at $500^{\circ} \mathrm{C}$ for three hours. The obtained powder was reground and heated at $900^{\circ} \mathrm{C}$ in air for $5 \mathrm{hr}$. Then, it was quenched to room temperature. Powder image was observed by electron transmission microscopy (CM 20 TEM, Philips, $200 \mathrm{KV}$ ). 
For the preparation of the positive electrode, $0.25 \mathrm{~g}$ of polyvinyl difluoride (Aldrich) was dissolved in about $12 \mathrm{~mL}$ of N-methyl-2-pyrrolidone for $1 \mathrm{hr}$ and then $4.5 \mathrm{~g}$ of the sample powder and $0.25 \mathrm{~g}$ of Super P black (MMM Carbon Co.) were added. After $24 \mathrm{hr}$ of ball mill processing, the viscous slurry was coated onto aluminum foil using a doctor blade and dried at $90^{\circ} \mathrm{C}$ in an oven. The obtained cathode film was hot pressed at $100^{\circ} \mathrm{C}$. The thickness of the cathode film was about $30 \mu \mathrm{m}$. The electrochemical cell was assembled in a dry room using the above positive electrode, lithium, a porous polyethylene film, and a $1 \mathrm{M} \mathrm{LiPF}_{6}$ solution in $1: 1$ volumetric ratio of ethylene carbonate/ dimethyl carbonate. Cells were subjected to galvanostatic cycling using a Toyo charge-discharge system before and after storage. All ageing test cells were initially cycled in the voltage range of $4.8-2.0 \mathrm{~V}$ and then charged to $4.6 \mathrm{~V}$. The charged cells were stored in a chamber maintained at a constant temperature of $25^{\circ} \mathrm{C}$ or $90^{\circ} \mathrm{C}$ for a week for the ageing test. The impedance measurement was carried out by a impedance/grain phase analyzer (Solartron SI 1260) in conjunction with a potentiostat (Solartron SI 1287) equipped with Z-view software, where an $\mathrm{AC}$ voltage of $5 \mathrm{mV}$ amplitude was applied over the frequency range of $0.1 \mathrm{~Hz}$ to $100 \mathrm{KHz}$.

$\mathrm{X}$-ray diffraction (XRD) patterns were obtained on the cathode electrode using a Philips X-ray diffractometer in the $2 \theta$ range of $15^{\circ}$ to $70^{\circ}$ with monochromatized $\mathrm{Cu}-\mathrm{K}_{\alpha}$ radiation ( $(\lambda=1.5406 \AA$ ). Differential scanning calorimetry (DSC) samples for the cathode were prepared by charging the cells to 4.6 or $4.8 \mathrm{~V}$ at the slow rate of $0.05 \mathrm{C}$. These cells were then disassembled in a dry room to remove the charged positive electrode. $5 \mathrm{mg}$ of the positive electrode (4.5 mg of cathode powder) and $3 \mu \mathrm{L}$ of fresh electrolyte were sealed in a high pressure DSC pan. The heating rate and temperature range of the DSC tests were $5^{\circ} \mathrm{C} / \mathrm{min}$ and $25-300^{\circ} \mathrm{C}$, respectively.

\section{Results and Discussion}

The bright field transmission electron microscopy image of $\mathrm{Li}\left[\mathrm{Co}_{0.1} \mathrm{Ni}_{0.15} \mathrm{Li}_{0.2} \mathrm{Mn}_{0.55}\right] \mathrm{O}_{2}$ powders is shown in Figure $\mathrm{I}$. The powders were made up of $0.1-0.2 \mathrm{tm}$ primary particles and the powder size ranged from $0.3-0.6 \mathrm{~mm}$. Small particle size may lead to good rate performance when used for high power lithium batteries. Before the ageing test, the cells were initially charged to $4.8 \mathrm{~V}$ and then discharged to $2.0 \mathrm{~V}$. Some of the Mn-based oxide with a layered structure including $\mathrm{Li}\left[\mathrm{Co} \mathrm{O}_{0.1} \mathrm{Ni}_{0.15} \mathrm{Li}_{0.2} \mathrm{Mn}_{0,55}\right] \mathrm{O}_{2}$ showed an irreversible initial charge-discharge profile. Therefore, the ageing test was performed after one cycle to prevent side effects by the initial irreversible reaction. The origin of this irreversible reaction has been previously reported..$^{+-8}$ After the initial cycle, the cells were charged to $4.6 \mathrm{~V}$ and stored at a constant temperature of $25^{\circ} \mathrm{C}$ or $90^{\circ} \mathrm{C}$ for 1 week. For initial cycling, a cut-off voltage of $4.8 \mathrm{~V}$ was used to generate enough initial irreversible reaction, which resulted in an increase of discharge capacity. ${ }^{+-8}$ However, electrolyte can

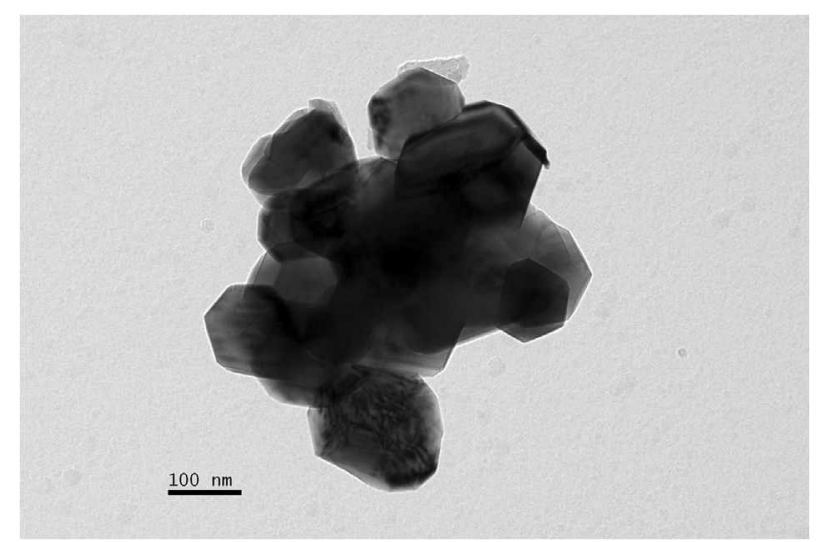

Figure 1. TEM bright field inage of $\mathrm{Li}\left[\mathrm{Co}_{0.1} \mathrm{Ni}_{0.1} \mathrm{Lin}_{0.2} \mathrm{Mn}_{0 \leqslant 3}\right] \mathrm{O}_{2}$ powder.
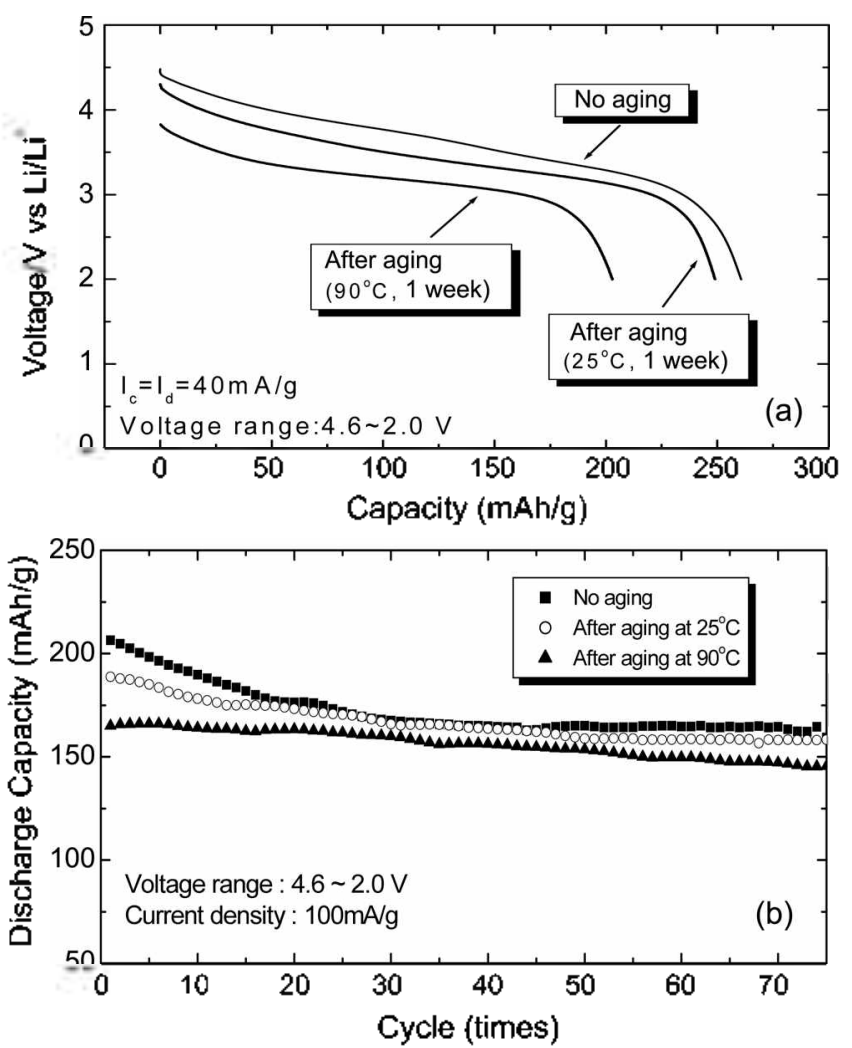

Figure 2. (a) The discharge profiles measured before and after ageing. (b) Cyclic performance for the $\mathrm{Li}\left[\mathrm{Co}_{0.1} \mathrm{Ni}_{0.15} \mathrm{Li}_{0.2} \mathrm{Mn}_{0.55}\right] \mathrm{O}_{2}$ electrode measured before and after ageing in the voltage range of 4.6-2.0 V at a current density of $100 \mathrm{mn}^{-1}$..$\Lambda 1$ samples werc pretreated with initial cycling in the voltage range of $4.8-2.0 \mathrm{~V}$ and then charged to $4.6 \mathrm{~V}$ before testing.

be easily decomposed during the ageing period at the high charge voltage of $4.8 \mathrm{~V}$. Therefore, a slightly lower cut-off voltage of $4.6 \mathrm{~V}$ was applied for the ageing test to reduce the effects originating from electrolyte decomposition on electrochemical properties. Considering that $\mathrm{LiCoO}_{2}$ with a layered structure similar to $\mathrm{Li}\left[\mathrm{CO}_{0.1} \mathrm{Ni}_{0.15}^{i} \mathrm{Li}_{0.2} \mathrm{Mn}_{0.55}\right] \mathrm{O}_{2}$ decomposed at cell voltages higher than $4.35 \mathrm{~V},{ }^{17}$ the charged state at $4.6 \mathrm{~V}$ is sufficient to check the resistance of the samples to ageing effects. 
The discharge profiles for the samples before and after ageing are presented in Figure 2a. The open circuit voltage (OCV) measured right after the charge process was $\sim 4.48 \mathrm{~V}$. The discharge capacity of the sample charged to $4.6 \mathrm{~V}$ before ageing was $-260 \mathrm{mAhg}^{-1}$ at a current density of 40 $\mathrm{mAg}^{-1}$ with a $0.2 \mathrm{C}$ rate. As expected, the open circuit voltage and discharge capacity for aged samples decreased depending on the ageing conditions. The $\mathrm{OCV}$ and discharge capacity for the sample aged at $25^{\circ} \mathrm{C}$ for 1 week were $\sim 4.3$ $V$ and $250 \mathrm{mAhg}^{-1}$, respectively. Meanwhile, the decrease of $\mathrm{OCV}$ and discharge capacity for the sample aged at $90^{\circ} \mathrm{C}$ for 1 week were more significant. The $\mathrm{OCV}$ decreased to $\sim 3.8$ $\mathrm{V}$ and the discharge capacity dropped to $200 \mathrm{mAhg}^{-1}$ at the specific current of $40 \mathrm{mAg}^{-1}$ with a $0.2 \mathrm{C}$ rate. Capacity loss during ageing at $90{ }^{\circ} \mathrm{C}$ was about $23 \%$. It is not surprising that the ageing effect for the cell aged at $90^{\circ} \mathrm{C}$ is more prominent, because the chemical reaction between the electrolyte and the surface of both electrodes will increase at higher temperatures. The ageing effect on cyclic perfornance was investigated as shown in Figure $2 b$. The measurements were carried out at a constant current density of $100 \mathrm{mAg}^{-1}$ with a $0.5 \mathrm{C}$ rate which, in order to reduce test time, were higher than the measurement conditions of the discharge profile shown in Figure 2a. The cell aged at room temperature seems to be recovered on subsequent cycling process. A slightly lower discharge capacity, less than $5 \%$ lower than that of the cell before ageing, was observed during several cycles but it was almost fully recovered after the $15^{\text {th }}$ cycle. The capacity loss accelerated with ageing at $90^{\circ} \mathrm{C}$ and it was not perfectly recovered on subsequent cycling, indicating that there was irreversible capacity loss. Some portion of the capacity loss on ageing is due to re-intercalation of lithium ions into the cathode from the electrolyte with charge transfer. However, considering the irreversibility of capacity loss, this effect is unlikely to be due solely to a chemical reaction involving charge transfer between the electrolyte and the electrode because charge transfer could be reversibly recovered. Thus, it is obvious that other reactions lead to the irreversible capacity loss during the ageing process. One of the intriguing observations is the fact that the ageing process did not deteriorate the cyclic property. On the contrary, the capacity difference between the aged cell and un-aged cell decreased with an increase of cycles. Despite some irreversible capacity loss, the damage of electrochemical properties induced by ageing is not critical, considering the fact that the cell still delivered considerable capacity in subsequent cycling after the storage test.

$\mathrm{AC}$ impedance analysis is a powerful technique to determine the kinetic parameters of the electrode process. ${ }^{20-23}$ Figure 3 presents impedance spectra for the $\mathrm{Li}\left[\mathrm{Co}_{0.1} \mathrm{Ni}_{0.15^{-}}\right.$ $\left.\mathrm{Li} \mathrm{i}_{2.2} \mathrm{Mn}_{0.55}\right] \mathrm{O}_{2}$ electrode in the charged state of $4.6 \mathrm{~V}$ before and after storage. Generally, impedance spectra for the lithium battery test cell containing cathode material exhibit two semicircles and a line inclined at a constant angle to the real axis. The equivalent circuit for this cell system is depicted in Figure 4a. In the equivalent circuit, $R_{b}$ is the bulk resistance of the electrolyte, separator, and electrode. $\mathrm{C}_{\mathrm{se}}$

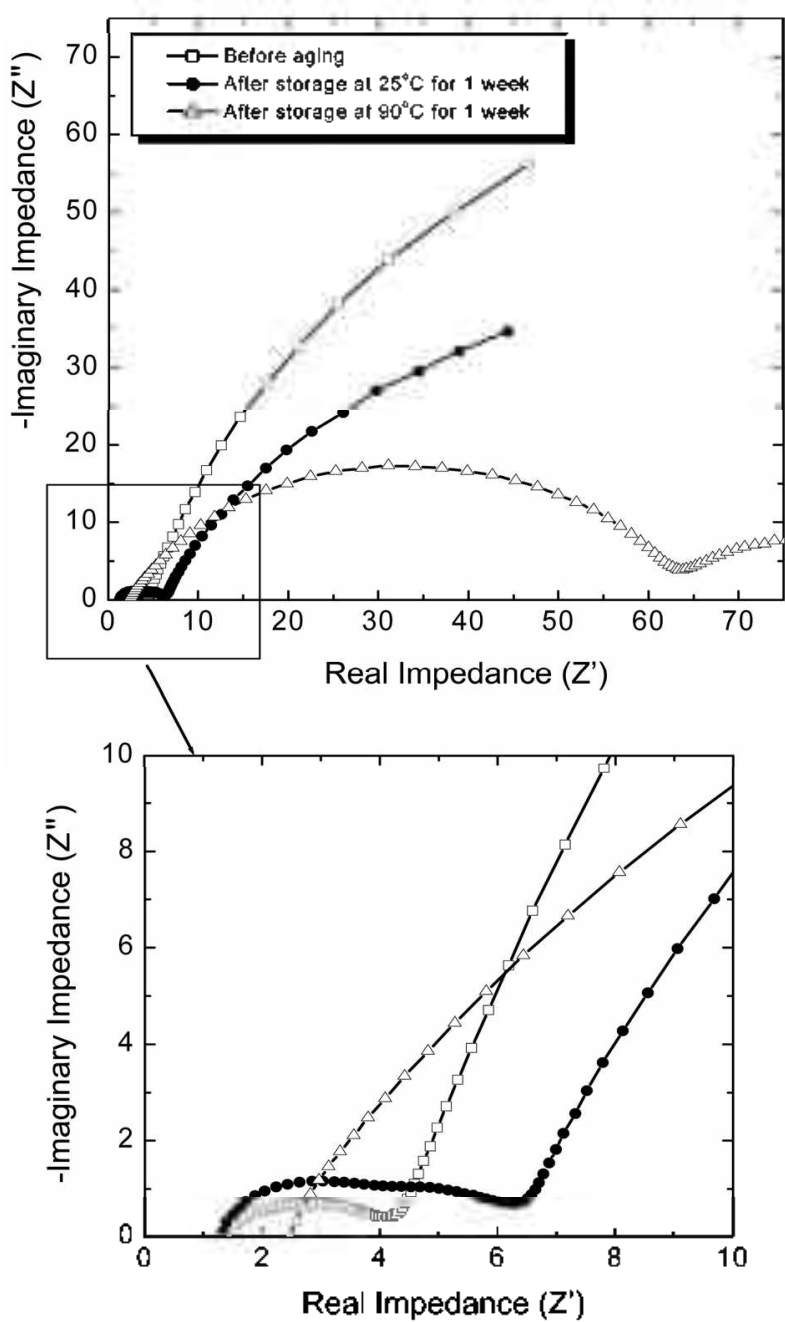

Figure 3. Nyquist plot for the cell containing the Li[Con.1 $\mathrm{Nin}_{\text {. }}$ $\mathrm{Li}_{02} \mathrm{Mn}_{0.55} \mathrm{O}_{2}$ electrode before and after ageing at $25^{\circ} \mathrm{C}$ or $90^{\circ} \mathrm{C}$ for 1 week. The high frequency range is enlarged in the below graph.

and $R_{s e i}$, which correspond to the first semicircle at high frequency, have experienced the capacitance and the resistance of the solid-state interface layer, which is formed in the highly charged state due to a passivation reaction between the electrolyte and the surface of the electrode. ${ }^{21,24,25}$ However, some researchers have reported that the first semicircle is related to particle-to-particle contact resistance..$^{26,27}$ $\mathrm{C}_{\mathrm{dl}}$ and $\mathrm{R}_{\mathrm{cls}}$ which is associated with the second semicircle at a medium frequency, are the double layer capacitance and charge transfer resistance. $\mathrm{W}$ is the Warburg impedance arising from the semi-infinite diffusion of $\mathbf{L i}$ ions in the positive electrode, which is generally indicated by a straight sloping line in the low frequency region.

The impedance plot before ageing shows two partially overlapped semicircles and a straight sloping line. Although not very noticeable, both semicircles of the impedance spectrum increased slightly after ageing at $25^{\circ} \mathrm{C}$. The increase of impedance of the cell aged at $90^{\circ} \mathrm{C}$ was more prominent. Two partially overlapped semicircles changed to one depressed extra large semicircle suggesting a dramatic 
(a)

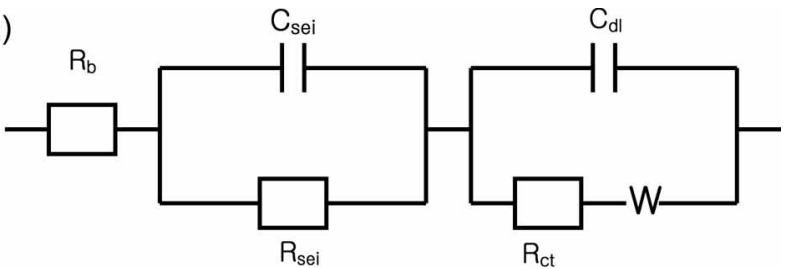

(b)

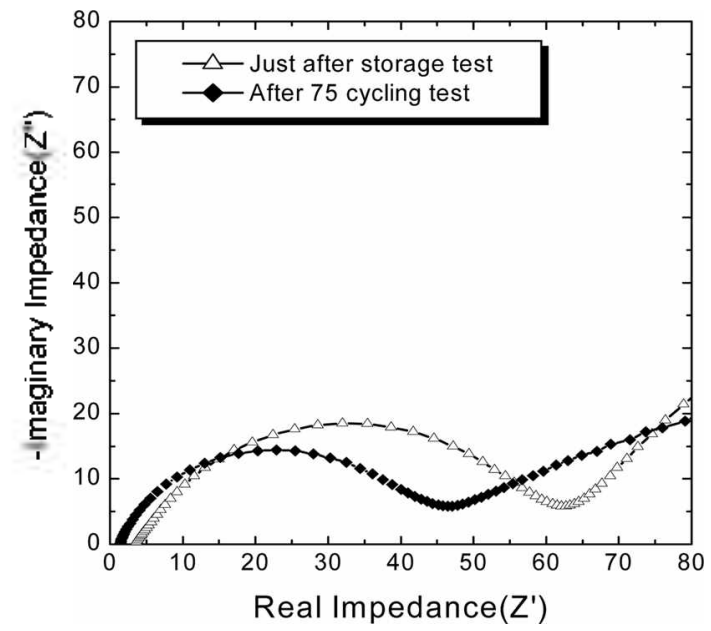

Figure 4. (a) Typical equivalent circuit for the cell system and (b) the change of the impedance spectra of the aged cell at $90^{\circ} \mathrm{C}$ upon subsequent cycling testing. The charge and discharge were carried out at a $0.5 \mathrm{C}$ rate in the voltage range of $4.6-2.0 \mathrm{~V}$ and the measurement was performed in the discharged state $(2.0 \mathrm{~V})$.

increase of $\mathrm{C}_{\text {sei, }} \mathrm{R}_{\mathrm{sei}}, \mathrm{C}_{\mathrm{dl}}$, and $\mathrm{R}_{\mathrm{cl}}$ due to the ageing effect. It is presumed that structural change of active material, chemical dissolution of transition metal ion, surface film formation, and oxidation of electrolyte may result in a remarkable increase of impedance during ageing at $90^{\circ} \mathrm{C}^{26,28-31}$ When the temperature is increased, the oxidizing properties of the positive electrodes against the electrolyte become the most important ageing factor, ${ }^{32}$ which may contribute to the deterioration of the discharge capacity after ageing at $90^{\circ} \mathrm{C}$.

Figure $4 \mathrm{~b}$ shows the change of the impedance spectra of the aged cell at $90^{\circ} \mathrm{C}$ during a subsequent cycling test. Charge and discharge was carried out at a $0.5 \mathrm{C}$ rate in the voltage range of $4.6-2.0 \mathrm{~V}$ and the measurements were performed at a discharged state to $2.0 \mathrm{~V}$. The electrochemical reaction of the cathode material proceeds as an insertion reaction of lithium ions in the metal oxide on cycling. The insertion/extraction of lithium ions leads to changes in the molar volume of the materials, which may induce mechanical stress and strain to the oxide particles. In addition, the phase transition can occur on cycling resulting in a distortion of the crystal lattice and further mechanical stress. Thus, the impedance of the positive electrode generally increased during cycling. ${ }^{26}$ In contrast, the impedance of the aged cell at $90^{\circ} \mathrm{C}$ was somewhat decreased during subsequent cycling. This may be attributed to the destruction of some portion of the surface film induced by high temperature storage because of the contraction and expansion of the volume of the electrodes during the intercalation and deintercalation process. Other factors, such as structural

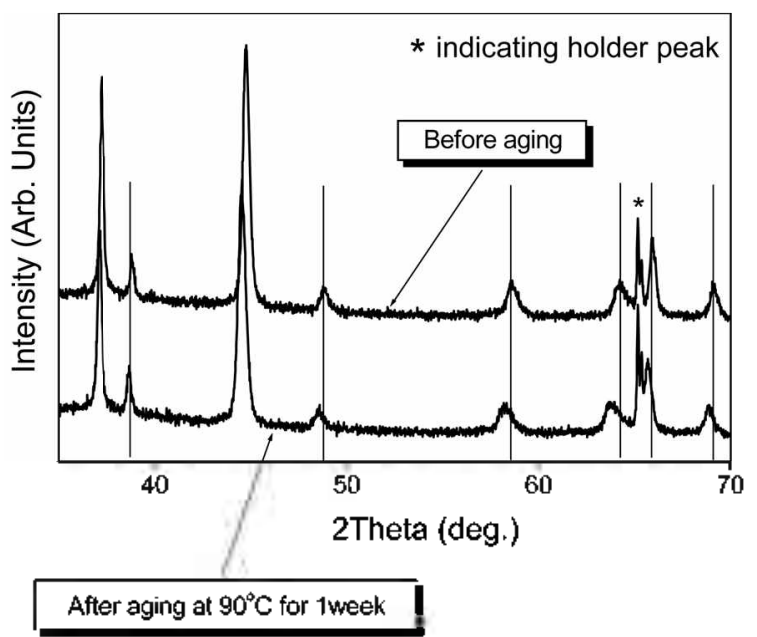

Figure 5. XRD patterns for the $\mathrm{Li}\left[\mathrm{Co}_{0.1} \mathrm{Ni}_{0.15} \mathrm{Li}_{0.2} \mathrm{Mn}_{0.55}\right] \mathrm{O}_{2}$ electrode before and after ageing. All samples were in the filly charged state $(4.6 \mathrm{~V})$.

change, dissolution of metal oxide ions, and surface reaction with electrolyte, can affect on impedance of the electrode, but these factors is not likely to be improved during cycling. There is no doubt that a surface film can be formed during prolonged cycling. However, this effect is negligible when it compared with the surface film effect originating from high temperature storage. This observation is consistent with the good cyclic properties of the sample aged at $90^{\circ} \mathrm{C}$, as shown in Figure $2 b$.

The structural changes for the fully charged $\mathrm{Li}\left[\mathrm{Co}_{0.1} \mathrm{Ni}_{0.15-}\right.$ $\mathrm{Li} 0_{2} \mathrm{Mn}_{0,5} \mathrm{O}_{2}$ electrode during ageing at $90^{\circ} \mathrm{C}$ was observed by XRD as shown in Figure 5. The electrode was prepared by disassembling the fully charged cell at $4.6 \mathrm{~V}$ before and after ageing. The peaks of the diffraction pattem of the post aged sample shifted to a lower angle and became slightly broad. The shift of peaks is likely due to lattice expansion induced by the re-intercalation of lithium ions into the structure from electrolytes, which is responsible for the capacity loss after storage as shown in Figure $3 \mathrm{~b}$. However, since lithium intercalation is basically reversible, it alone can account for the reversible capacity loss. The irreversible loss of capacity after storage can be explained by the irreversible reaction. The increase of impedance induced by a number of changes on the cathode due to ageing was detected in Figure 3. However, we cannot observe any peak that can be assigned to an impurity formed from an irreversible reaction. Considering the impedance analysis, it is possible that some structural change is induced by ageing at high temperature. However, its structural change could be not detected in XRD analysis due to its detection limit, otherwise it is not serious and/or occurs only on the surface of the electrode.

The thermal stability of the fully charged $\mathrm{Li}\left[\mathrm{Co}_{0.1} \mathrm{Ni}_{0.15-}^{-}\right.$ $\left.\mathrm{Li}_{0} \mathrm{Mn}_{0.55}\right] \mathrm{O}_{2}$ electrode was tested by performing a differential scanning calorimetry (DSC) measurement. The thermal stability of cathode materials, especially in the charged state, is an important factor for practical applications. Figure $6 \mathrm{a}$ displays the DSC profile of the charged sample before 


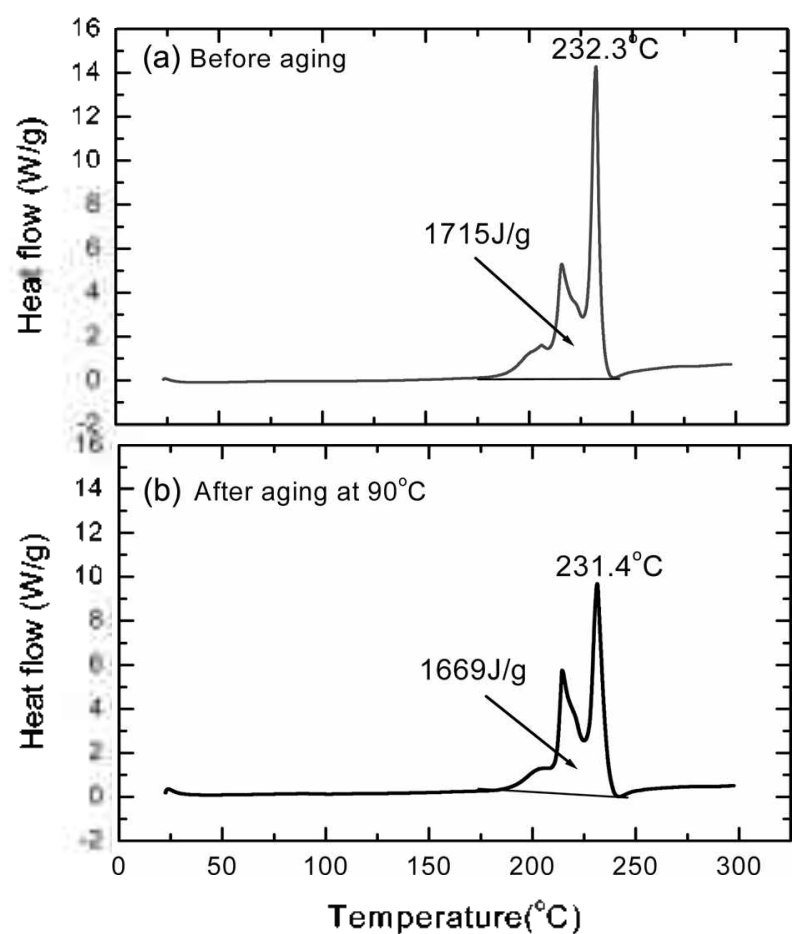

Figure 6. Differential scanning calorimetry (DSC) profiles of $\mathrm{Li}\left[\mathrm{Co}_{0,1} \mathrm{Ni}_{0,15} \mathrm{Li}_{0,2} \mathrm{Mn}_{0,5}\right] \mathrm{O}_{2}$ electrode (a) before ageing and (b) after ageing. All samples were in the fully charged state $(4.6 \mathrm{~V})$.

storage. The sample started thermally reacting with the electrolyte around $180^{\circ} \mathrm{C}$ and proceeded to thermal runaway at $232{ }^{\circ} \mathrm{C}$. One large and two small exothermic peaks produced $1,715 \mathrm{Jg}^{-1}$ of heat. The storage effect at $90^{\circ} \mathrm{C}$ for one week on the DSC profile is displayed in Figure $6 \mathrm{~b}$. The differences of the exothermic peaks' shapes before and after ageing were very small. The intensity of the major peak was somewhat decreased and all exothermic peaks produced slightly less heat $\left(1,669 \mathrm{Jg}^{-1}\right)$ after the storage process, which shows the thermal stability of the sample was not exacerbated by the storage process at $90^{\circ} \mathrm{C}$.

\section{Conclusions}

The electrochemical and structural properties of a $\mathrm{Li}\left[\mathrm{CO}_{0,1.1} \mathrm{Ni}_{0,15} \mathrm{Li}_{0}, \mathrm{Mn}_{0.55}\right] \mathrm{O}_{2}$ electrode were examined before and after the ageing process at room temperature and $90^{\circ} \mathrm{C}$. The discharge capacity of the cell containing the $\mathrm{Li}\left[\mathrm{CO}_{0.1}{ }^{-}\right.$ $\left.\mathrm{Ni}_{0.15} \mathrm{Li}_{0.2} \mathrm{Mn}_{0.55}\right] \mathrm{O}_{2}$ electrode decreased upon ageing at $25^{\circ} \mathrm{C}$ and $90^{\circ} \mathrm{C}$ due to a number of ageing effects. The capacity loss of the cell aged at $25^{\circ} \mathrm{C}$ was nearly recovered upon subsequent cycling. However, that of the cell aged at $90^{\circ} \mathrm{C}$ displayed irreversibility, demonstrating that an irreversible reaction occurred during the ageing period. The impedance of the cell was dramatically increased after ageing at $90^{\circ} \mathrm{C}$. It could be possible that some structural change was induced by ageing at high temperature. However, that was not detected by XRD analysis due to its detection limit. The thermal stability of the $\mathrm{Li}\left[\mathrm{Co}_{0.1} \mathrm{Ni}_{0.15} \mathrm{Li}_{0.2} \mathrm{Mn}_{0.55}\right] \mathrm{O}_{2}$ electrode was sustained during the high temperature ageing process.
Acknowledgements. This work was supported by the Korean Ministry of Information and Communication and the 2005 Research Fund of the University of Ulsan.

\section{References}

I. Hong, Y.-S.; Park, Y. J.; Ryu, K. S.; Chang, S. H.; Shin, Y.-J. J. Power Sources 2005, 147,214.

2. Ohzuku, T.; Makimura, Y. Chent. Lett. 2001, 744.

3. Numala, K.; Sakaki, C.; Yamanaka, S. Solid State lonics 1999, 117,257 .

4. Lu, Z.; Dahn, J. R. J. Electrochem. Soc, 2002, 149, Al454.

5. Lu, Z.: Dahn, J. R. J. Electrochem. Soc. 2002. 149, A815.

6. Robertson, A. D.; Bruce, P. G. Chent. Conmim. 2002, 2790.

7. Robertson, A. D.; Bruce, P. G. Chem. Mater. 2003, $15,1984$.

8. Armstrong, A. R.; Bruce, P. G. Electrochem. Solid-State Lett. 2004, 7(1), Al.

9. Yoon, W.-S.; Iannopollo, S.; Grey, C. P.; Carlier, D.; Dorman, J.; Reed, J.; Ceder, G Electrochem. Solid-State Lett, 2004, $7(7)$, A167.

10. Johnson, C. S.; Kim, J.-S.; Kropf, A. J.; Kahaian, A. J.; Vaughey, J. T.; Thackeray, M. M. J. Power Sotirces 2003, 119-121, 139.

11. Park, Y. J.; Kim, M. G.; Hong, Y.-S.; Wu, X.; Ryu, K. S.; Chang, S. H. Solid State Commun. 2003, $127,509$.

12. Park, Y. J.; Hong, Y.-S.; Wu, X.; Kim, M. G; Ryu, K. S.; Chang, S. H.J. Electrochen. Soc. 2002, 151, A720.

13. Park, Y. J.; Hong. Y.-S.; Wu, X.; Ryu, K. S.; Chang, S. H. $J$. Power Sources 2004, 129, 288.

14. Hong, Y.-S.; Park, Y. J.; Ryu, K. S.; Chang, S. H.; Kim, M. G J. Mater, Chem, 2004, I4, 1424 .

15. Hong, Y.-S.; Park, Y. J.; Ryu, K. S.; Chang, S. H. Solid State Ionics 2005, 176, 1035.

16. Wu, X.; Ryu, K. S.; Hong, Y.-S.; Park, Y. J.; Chang, S. H. $J$. Power Sontes 2004, 132, 219.

17. Gabrisch, H.; Ozawa, Y.; Yazami, R. Electrochimica Acta 2006, 52,1499 .

18. Aurbach, D.; Markovsky, B.; Talyossef, Y.; Salitra, G.; Kim, H.-J.; Choi, S. J. Power Sources 2006, 162, 780 .

19. Abraham, D.; Reynolds, E.; Sammann, E; Jansen, A.; Dees, D. Electrochinica Acta 2005, 51,502.

20. Troltzsch, U.; Kanoun, O.; Trankler, H. Electrochimica Acta $2006,51,1664$.

21. Zhou, W; Bao, S.; He, B.; Liang, Y.; Li, H. Electrochmica Acta 2006, $51,470 \mathrm{l}$.

22. Mohamedi, M.; Takahashi, D.; Itoh, T.; Umeda, M.; Uchida, I. $J$. Electrocheni. Soc. 2002, 149, A 19.

23. Orsini, F.; Dolle, M.; Tarascon, J.-M. Solid State lonics 2000, J35, 213.

24. Lu, C.-H.; Wang, H.-C. J. Eur. Ceram. Soc. 2004, 24, 7I7.

25. Fey, G. T.; Lu, C.-Z.; Kumar, T. P. J. Power Sources 2003, 115 , 332.

26. Vetter, J.; Novak, P.; Wagner, M. R.; Veit, C.; Moller, K.-C.; Besenhard, J. O.; Winter, M.; Wohllahrt-Mehrens, M.; Vogler, C.; Hammouche, A. J. Power Sources 2005, 147, 269.

27. Song, J. Y,; Lee, H. H.; Wang, Y. Y; Wan, C. C. J. Power Sonces 2002. $, 11,255$.

28. Spotnitz, R. J. Power Sotrces 2003, $1 J\}, 72$.

29. Arora, P.; White, R. E.; Doyle, M. J. Electrochem. Soc. 1998, 145, 3647.

30. Broussely, M.; Herreyre, S.; Biensan, P.; Kaszlejna, P.; Nechev, K.; Staniewiez, R. J. J. Power Sonces 2001, 97-98, 13.

31. Markovsky, B.; Rodkin, A.; Cohen, Y. S.; Palchik, O.; Levi, E.; Aurbach, D.; Kim, H. J.; Schimidt, M. J. Power Sources 2003 , 119,504.

32. Broussely, M.; Biensan, Ph.; Bonhomme, F.; Blanchard, Ph.; Herreyre, S.; Nechev, K.; Staniewiez, R. J. J. Power Sonces $2005,146,90$. 